\title{
DISCOVERY
}

\section{Ideological And Constitutional Study Of The White Chicken Of Sex Gland, Canal And Epithelial Duct.}

\author{
Dr. Manouchehr Shafiepour, Dr. Ahmad Baharsefat \\ Department Of Basic Science, Faculty Of Veterinary Medicine Tehran University \\ Iran
}

\begin{abstract}
This study was administered to research the microscopic anatomy and constitutional description of the male venereal tract in Iranian Native White Roosters (IWR). The liquid body substance tubules had a dense and compact organization. a mean of twelve layers of cells was seen within the liquid body substance tubules epithelial tissue. The spermatogonal cell layer showed some variation between totally different birds in 1-3 layers; but, the gametocyte, secondary spermatocytes and spermatids were organized in a pair of, 3-4 and 3-5 layers, severally. The testicles were oval in form, placed on the left and right sides of sheet, set on the caudal side of the lungs and also the ventral side of either the correct or left kidneys, and also the visceral surfaces of the left and right lobes of the liver. The canal wasn't divided into recognizable elements and was frontally connected to the corresponding sex gland on its dorsomedial side continuous with the epithelial duct. The ductuli efferentis were moderately giant with pseudostratified columnar epithelial tissue lined with 3 cell varieties, as well as ciliate, nonciliated and basal cells. The connective ducts were lined with scare ciliate pseudostratified columnar epithelial tissue. The epithelial tissue of the canal was pseudostratified and columnar, embedded in a very loose animal tissue. The proximal a part of the epithelial duct was lined with pseudostratified columnar epithelial tissue, that was continuous with easy cubelike epithelial tissue towards the distal portion.constitutional studies discovered an outsized sac-like accent method that consisted of 2 non-discrete elements within the frontoventricular region of the testes between the canal and also the epithelial duct, that was closely connected ventrally to the canal and laterally to the kidneys. This organ was lined with stratified cubelike epithelial tissue with thick clear tissue layer muscle. The adventitia sub tissue layer was evident, and also the outer layer was composed of a fibrous capsule with a well-developed tube-shaped structure offer. This steered that the role of the sac-like accent method was as AN organ to provide gamete, comparable to the tail of the canal in mammals.
\end{abstract}




\section{THE AMERICAN JOURNAL OF}

VETERINARY SCIENCES AND WILDLIFE

VOLUME01 ISSUE03

\section{DISCOVERY}

Key Words: Iranian white rooster; testes; epididymis; accent method.

\section{Introduction}

Studies on the event of the reproductive system of the poultry and variation within their ductless gland size from hatching to sexual maturity are of nice interest to those in the poultry business and different investigators In these investigations, Aire River with success delineated thehistology of the canal within the fowl, guinea, quail and duck. There are reports on the microanatomy of male fowls, sex gland adventitia tunica, liquid body substance tubules, plexus, epithelial duct and canal, sewer (Marvan, 1969), and sex gland plant tissue. Mercadante . (1982) administered investigations on the analyses of the anatomy of the venereal organs of the male columbiform bird, as well as the sex gland, epididymis, epithelial duct and also the sexual practice organ.

The aim of this study was to research microanatomical and macroanatomical options of the generative organs of the Iranian white chicken, that is one in every of the foremost reared birds within the world.albuginea of testes is formed from albuminoid animal tissue. The course of the sex gland blood vessel branches passes on those of anastomosing veins, that well-grooved the tube-shaped structure layer of this animal tissue (Figure 1). The liquid body substance tubules were found to own a dense and compact organization inside the sex gland tissue. The spermatogenic lineage, as well as spermatogonia, primary spermatocytes, secondary spermatocytes, spermatids and spermatozoa were determined within the epithelial tissue of liquid body substance tubules. on these cells, sustanticular (Sertoli) cells, conjointly determined. On average, twelve layers of cells were seen within the epithelial tissue of liquid body substance tubules. The spermatogonal cell layer showed some variation between totally different birds and these cells were organized in between one and 3 layers' but, the spermatocytes (A and B), secondary spermatocytes and spermatids were organized in a pair of, 3-4 and 3-5 layers severally. The interstitium of the testes was created from loose connectivetissue, that contained Leydig cells in shut neck of the woods to the arterioles and capillaries. The mode of distribution of those cells wasn't uniform. 


\section{THE AMERICAN JOURNAL OF}

VETERINARY SCIENCES AND WILDLIFE

\section{VOLUME01 ISSUE03}

\section{DISCOVERY}

\section{Materials and ways}

Ten mature and apparently healthy Iranian Native White Roosters were employed in this study. Initially, the animals were anaesthetized with Ketalar and euthanized victimization of dioxide gas. The generative organs, as well as the sex gland, epithelial duct and canal of the birds were compound and placed into $100 \%$ solution answer for fixation.

\section{Statistical analyses}

Data were analyzed victimization 2 ways that Analysis of Variance followed by Isadora Duncan $\mathrm{s}$ multiple vary take a look at. The SPSS code (version 15) was used.

\section{Results}

The geography relationship of those organs was as follows: they were set on the caudal side of the lungs and also the ventral side of the correct and left kidneys, and also the visceral surfaces of the left and right lobes of liver. The macromorphometric analysis of the correct and left testes failed to reveal important differences; but, in some cases the correct sex gland had comparatively predominant dimensions.

The latter organ ran on median line of body dorsomedial to the sex gland and its mean length was three $\mathrm{cm}$. different structures were evident, as well as the plexus, ductuli efferentis, connecting the ductules and ductus canal. The ductuli efferentis were connected to the plexus and concluded at connecting ductules. The connecting ductules were connected to the ductus canal at many places. The ductus canal continuing with a extremely convoluted ductus deferentis. 


\section{THE AMERICAN JOURNAL OF}

\section{DISCOVERY}

The epithelial tissue of the plexus was easy squamous or low cubelike, however abrupt changes into easy columnar were found at the start of the ductuli efferentis. The ductuli efferentis were moderately giant, with average diameter of 98-103 $\mu \mathrm{m}$. Their animal tissue sort was pseudostratified columnar and also the height of the cells was 19-21 $\mu \mathrm{m}$. The epithelial tissue was lined with 3 cell varieties, as well as ciliate, nonciliated and basal cells. Intraepithelial mononuclear immune cells, like lymphocytes, were determined within the ductuli efferentis and also the canal. The proof of secretary activity was discovered by the observation of blebbings on the surface of cells.

\section{Discussion}

The entire generative systems of the birds area unit necessary for breeding, however the testes, canal and epithelial duct area unit the foremost vital purposeful regions. The male genital system in male birds consists of the testes, epididymis, epithelial duct, ejaculatory region and sex activity organ. Lately, researchers have taken into thought studies on birds since they represent a wonderful organic process supply. There area unit many classical descriptions of the male generative tract, that aim at establishing a correlation with form, sex gland size, age and sexual maturity. However, roosters like game and fantastic birds haven't been sufficiently investigated anatomically and histologically. Therefore, this gift study aimed to research the genital system in Iranian white roosters.

Light research confirmed the presence of an outsized variety of ducts settled posteriomedial to every sex gland. The intracapsular \{rete sex gland|plexus|rete\} consisted of a rather expanded series of tubules embedded inside the animal tissue of the adventitia tunica within the testis (Barker and Marion, 1980). The high volume of animal tissue within the poultry canal is basically owing to the massive variety of mononuclear cells and humour nodes scattered unpredictably within the periductal tissues throughout the epididymal region within the quail and guinea (Aire, 1978). In similar findings to those of Aire River and Barker, a high degree of separation of the ducts was seen embedded within the animal tissue and, moreover, various mononuclear immune cells were scattered within the animal tissue. to boot, interepithelial lymphocytes were given within the lining epithelial tissue of the ducts. 


\section{THE AMERICAN JOURNAL OF}

VETERINARY SCIENCES AND WILDLIFE

VOLUME01 ISSUE03

\section{DISCOVERY}

The area obsessed by the ductus canal within the chicken was considerably beyond within the quail and guinea-fowl . Tingari (1971) determined that the chicken contains a tortoise-shell formed ductus canal. during this study, the proportion of the ductus canal was nearly a similar because the results of studies in chickens. The canal of the cock is split into a main half ANd an appendix canal (Budras and Sauer, 2004), whereas within the gift study there have been no separate compartments. many works believe our results with regards to the canal size and position and also the epithelial duct web site and tortuousity .

\section{References}

1. Aire, T.A.; Ayeni, J.S and Olowo-Okorun, M.O. (1989) The structure of the excurrent ducts of the sex gland of the guinea-fowl (Numida meleagnis). J. Anat.

2. Amer, F.I.; Shahin, M.A. (1980) The post-hatching development of the gonads within the fowl, . Ann. Zoo.

3. Artoni, S.M.B. (1998) Considerações sobre a morfología e a histofisiologia do testículo DA codorna (Coturnix cournix japónica).

4. Barker, S.G.E; Kendel, M. (1988) vertebrate plexus epithelial tissue. Poult. Sci.

5. Bennett, C.H. (1984) Relation between size and age of the gonads within the fowl from hatching date to sexual maturity. Poult. Sci.

6. Budras, K.D.; Sauer, T. (1985) Morphology of the canal of the cock and its result upon the gamete maturation method. Ster. Sex. Horm. Synth. J. 